\title{
Determination of Suitable Extractant for Estimating Plant Available Arsenic in Relation to Soil Properties and Predictability by Solubility-FIAM
}

\author{
Akanksha Raj · Jajati Mandal (D) Debasis Golui • Debjani Sihi • \\ Biswanath Dari · Preety Bala Kumari • Mainak Ghosh · Pritam Ganguly
}

Received: 26 February 2021 / Accepted: 4 June 2021 / Published online: 14 June 2021

(C) The Author(s) 2021

\begin{abstract}
Extractant for estimating plant available arsenic (As) in soil has not been universally established. Moreover, to assess and monitor the complex chemical behaviour of arsenic (As) in soil and subsequently its transfer in crops, a suitable extraction protocol considering the soil properties in relation to crop uptake is required. For this purpose, a pot experiment was conducted to evaluate the suitability of
\end{abstract}

A. Raj · J. Mandal $(\bowtie) \cdot$ P. B. Kumari · P. Ganguly

Department of Soil Science and Agricultural Chemistry,

Bihar Agricultural University, Sabour, India

e-mail: jajati.bckv@gmail.com

J. Mandal

School of Science Engineering and Environment,

University of Salford, Salford, UK

D. Golui

Division of Soil Science and Agricultural Chemistry,

Indian Agricultural Research Institute, New Delhi, India

D. Sihi

Department of Environmental Sciences, Emory University, Atlanta, GA, USA

B. Dari

Crop and Soil Sciences Department, Oregon State

University, Oregon, USA

M. Ghosh

Department of Agronomy, Bihar Agricultural University,

Sabour, India the extractants for determination of extractable As in soil and risk assessment by solubility-free ion activity model (FIAM) with rice (variety: Sushk Samrat) as the test crop. Soil in bulk was collected from six locations of Indo-Gangetic Plain of Bihar, India, varying in physicochemical properties to conduct the pot experiment using five doses of As $(0,10,20$, 40 and $80 \mathrm{mg} \mathrm{kg}^{-1}$ ). Six extractants namely $0.2(\mathrm{M})$ $\mathrm{NH}_{4}$-oxalate, $0.05(\mathrm{~N}) \mathrm{HCl}+0.025(\mathrm{~N}) \mathrm{H}_{2} \mathrm{SO}_{4}, 0.5$ (M) $\mathrm{KH}_{2} \mathrm{PO}_{4}, 0.5(\mathrm{~N}) \mathrm{NH}_{4} \mathrm{~F}, 0.5(\mathrm{M}) \mathrm{NaHCO}_{3}$ and 0.5 (M) EDTA were used. The results revealed that 0.5 (M) $\mathrm{KH}_{2} \mathrm{PO}_{4}$ gave the best correlation with the soil properties and crop uptake and can be considered a suitable extractant of As. Regardless of the As dose and the soil type used, in rice tissue, concentration of As followed the order root $>$ straw $>$ leaf and grain. As high as $94 \%$ variation in As content in rice grain could be explained, when $0.5(\mathrm{M}) \mathrm{KH}_{2} \mathrm{PO}_{4}$ extractable As is being used as input for solubility-FIAM. Extractable As cannot be determined by atomic absorption spectrophotometer (AAS) coupled with vapour generation accessory (VGA) when 0.5 (M) EDTA was used as an extractant.

Keywords Arsenic $\cdot$ Extractant $\cdot$ Correlation studies $\cdot$ Hazard quotient $\cdot$ FIAM 


\section{Introduction}

Arsenic (As) in groundwater is of great environmental apprehension and one of the greatest contamination problems in the world. It is a poisonous trace element affecting many countries of the world including the Indo-Gangetic plain of India (Sanyal et al., 2015). Drinking water is one of the most important pathways through which humans are exposed to As and continuous consumption of As contaminated drinking water results in arsenicosis. Consumption of foods grown on As contaminated soils can be another route of human exposure to As. Meharg (2004)reported accretion of As in rice grain which proved to be calamity for rice consuming areas of South East Asia. Total As content ranging from 10 to $20 \mathrm{mg} \mathrm{kg}^{-1}$ in soil has found to be a guide of As hazard (Rahaman et al., 2013). Elated levels of As has also been reported in soils from contaminated districts of Bhojpur, Bhagalpur, Begusarai, Patna and Katihar of Bihar (Singh, 2011; Singh \& Ghosh, 2012; Singh et al., 2014).

Soil, acting as a sink for As, becomes a potent source for soil-crop transfer and thus increases the health hazard to the humans through consumption of harvested produce. Therefore, proper assessment and monitoring of bioavailable As are necessary which can be achieved by using different extractants. Different analytical methods are available which can extract As from the various pools of soil. Extractant like $1(\mathrm{~N}) \mathrm{NH}_{4} \mathrm{Cl}, 0.5(\mathrm{~N}) \mathrm{NH}_{4} \mathrm{~F}$, saturated $\mathrm{NaCl}$ and $0.5(\mathrm{~N}) \mathrm{H}_{2} \mathrm{SO}_{4}$ were used for determining As in neutral soil, and $0.5(\mathrm{~N}) \mathrm{NH}_{4} \mathrm{~F}$ was found to be the best extractant among all as reported by Johnston and Barnard (1979). However, when $0.2(\mathrm{M}) \mathrm{NH}_{4}$-oxalate was assessed with varying the shaking period for determining As in soil, $0.17 \mathrm{~h}$ of shaking was found to be the best one (Wenzel et al., 2001). Trang Hoang and Hahn (2015) studied the As fractionation in the agricultural soils of Vietnam using the extractants like $0.05(\mathrm{M})\left(\mathrm{NH}_{4}\right)_{2} \mathrm{SO}_{4}, 0.05$ (M) $\left(\mathrm{NH}_{4}\right) \mathrm{HPO}_{4}, 0.2$ (M) $\mathrm{NH}_{4}$-oxalate buffer, 0.2 (M) $\mathrm{NH}_{4}$-oxalate buffer $+0.1 \mathrm{M}$ ascorbic acid $(\mathrm{pH}=3.25)$ and $\mathrm{HNO}_{3} / \mathrm{H}_{2} \mathrm{O}_{2}$. Van Nguyen et al. (2017)studied the As speciation and extraction methodologies, where six different extractants were used. For non-specifically bound As, 0.05 (M) $\left(\mathrm{NH}_{4}\right)_{2} \mathrm{SO}_{4}$ was used, and for specifically bound As,
$0.05 \mathrm{M}\left(\mathrm{NH}_{4}\right) \mathrm{H}_{2} \mathrm{PO}_{4}$ was used. In case of amorphous iron, aluminium and manganese oxide bound As, $0.2(\mathrm{M}) \mathrm{NH}_{4}$-oxalate $(\mathrm{pH}=3.25)$ performed better, and for crystalline iron bound As, it was $0.2(\mathrm{M})$ $\mathrm{NH}_{4}$-oxalate $+0.1(\mathrm{M})$ ascorbic acid $(\mathrm{pH}=3.25)$. The organic matter bound As was determined by $\mathrm{H}_{2} \mathrm{O}_{2}+\mathrm{HNO}_{3} \quad(\mathrm{pH}=2)$ and secondary sulphide bound As by $3.2(\mathrm{M}) \mathrm{NH}_{4} \mathrm{O}$ Ac in $20 \% \mathrm{HNO}_{3}$ and lastly for total As, $\mathrm{HNO}_{3}$ was used. For residual form, the mixture of all the extractant except those of total As was used. The suitability of an extractant does not depend only on its extracting ability. Hence, crop uptake studies should be integrated with studies that evaluate extractable As by different extractants to determine the suitable extractant, which is seldom reported.

The risk to human health from ingestion of As can be expressed in terms of hazard quotient (HQ) (Rahman et al., 2013; Golui et al., 2017; Mandal et al., 2019a, b). Extraction of As using different extraction protocols will result in a disparity of extractable As in soil. Hence, a comparison between the extractants can be undertaken by using the semi empirical model like solubility-free ion activity model, which can also help in identification of the suitable extractant in terms of prediction coefficient. In the early 1980s, FIAM was conceptualized for prediction of metal transport from soil to plant following the principles of biotic ligand model and soil $\mathrm{pH}$, organic carbon and extractable metal have been used as input for this model (Datta $\&$ Young, 2005). Later on, uses of solubility-FIAM to predict several metals and metalloids including As in plant have been reported successfully by several authors, based on the free ion activity of metal and metalloid in soil solution (Meena et al., 2016; Golui et al., 2017; Mandal et al., 2019a, b and Kumari et al., 2021). However, there is no information on the application of solubility-FIAM for predicting suitability of extractant in relation to plant uptake as well important soil chemical properties like $\mathrm{pH}$ and organic carbon. A suitable soil analysis for determining extractable As must take into account a number of soil chemical factors and at the same time be amenable to routine operation in laboratory. It should also be appreciated that since a single test cannot be recommended for all soils, selection of an extractant that may predict As availability in a particular group of soil is important. To delineate the suitable extractant, correlation with the soil properties and plant As content is also 
required. Therefore, in this study, a modest initiative has been undertaken to assess the suitability of different extraction procedures for determining the plant available As in relation to soil properties and crop uptake.

\section{Materials and Methods}

\subsection{Sampling of Soil and Analysis of Soil and Plant Samples}

The soils used for the pot experiment were collected from 6 different locations: Bihar Agricultural University (BAU) Farm $\left(\mathrm{S}_{1}\right)$, Mamalkha $\left(\mathrm{S}_{2}\right)$, Ghogha $\left(\mathrm{S}_{3}\right)$, Amarpur $\left(\mathrm{S}_{4}\right)$, Tarapur $\left(\mathrm{S}_{5}\right)$ and Ekchari $\left(\mathrm{S}_{6}\right)$ of the Indo-Gangetic plain of Bihar, India. The soils belong to Inceptisols $\left(\mathrm{S}_{1}, \mathrm{~S}_{2}, \mathrm{~S}_{3}, \mathrm{~S}_{4}, \mathrm{~S}_{5}\right)$ and Alfisols $\left(\mathrm{S}_{6}\right)$ order. They were analysed for $\mathrm{pH}$ (Datta et el., 1997), texture (Bouyoucos, 1962) and organic carbon (C) (Walkley \& Black, 1934). The available nutrients in soil like nitrogen $(\mathrm{N})$ was measured by the method outlined by Subbiah \& Asija (1956), phosphorus (P) by Olsen et al. (1954) and potassium (K) by Knudsen et al. (1982). Estimation of iron ( $\mathrm{Fe})$ and manganese $(\mathrm{Mn})$ oxides were done using acidic ammonium oxalate extraction method (McKeague \& Day, 1966). Six extraction methodologies with 0.5 (M) $\mathrm{NaHCO}_{3}$, $0.5(\mathrm{M}) \mathrm{KH}_{2} \mathrm{PO}_{4}, 0.5(\mathrm{~N}) \mathrm{NH}_{4} \mathrm{~F}, 0.5(\mathrm{M})$ EDTA, $0.2(\mathrm{M}) \mathrm{NH}_{4}$-oxalate and $0.05(\mathrm{~N}) \mathrm{HCl}+0.025(\mathrm{~N})$
$\mathrm{H}_{2} \mathrm{SO}_{4}$ were used to determine the plant available As as depicted in Supplementary Table S1. Tri-acid was used for total As analysis in plant samples as outlined by (Mandal et al., 2019a).

\subsection{Pot Experiment}

Rice crop (variety: Sushk Samrat) was grown in pots and spiked with 5 levels of As (0, 10, 20, 40 and $80 \mathrm{mg} \mathrm{L}{ }^{-1}$ labelled as $\mathrm{As}_{0}, \mathrm{As}_{10}, \mathrm{As}_{20}, \mathrm{As}_{40}, \mathrm{As}_{80}$, respectively) in 2019. In each pot, 5-7 rice seeds were sowed, and after 10 days, only 2 (two) healthy seedlings were kept for conducting the experiment. The physical and chemical properties of the experimental soil have been depicted in Table 1. Each treatment was replicated thrice. The soils were treated with reagent grade urea, potassium dihydrogen phosphate and potassium chloride to provide $\mathrm{N}, \mathrm{P}$ and $\mathrm{K}$ at the rate of 100,60 and $40 \mathrm{~kg} \mathrm{ha}^{-1}$, respectively. Irrigation was given, as and when required, using deionized water to maintain the optimum moisture condition, i.e., field capacity. The experiment was conducted as a two-way (soil type and arsenic dose) completely randomized design (CRD) with three replications using a total of 90 (6 X 5 X 3) pots. Plant samples were harvested at maturity, i.e., 120 days after sowing. After harvesting, processed plant samples were processed for analysis following Mandal et al. (2019a). Effect of As dose on yield of rice grain is presented as Supplementary Table S2. After harvest of crop, soil was taken out

Table 1 Physicochemical characteristics of the soil samples used in the study

\begin{tabular}{|c|c|c|c|c|c|c|c|}
\hline \multirow[t]{2}{*}{ Soil properties } & \multirow[b]{2}{*}{ Unit } & \multicolumn{6}{|l|}{ Site locations } \\
\hline & & $\mathrm{S}_{1}$ & $\mathrm{~S}_{2}$ & $\mathrm{~S}_{3}$ & $\mathrm{~S}_{4}$ & $\mathrm{~S}_{5}$ & $\mathrm{~S}_{6}$ \\
\hline $\mathrm{pH}$ & - & $7.76 \pm 0.06$ & $7.51 \pm 0.03$ & $7.43 \pm 0.05$ & $6.21 \pm 0.02$ & $6.17 \pm 0.07$ & $6.40 \pm 0.03$ \\
\hline $\mathrm{OC}$ & $\%$ & $0.56 \pm 0.05$ & $0.62 \pm 0.06$ & $0.66 \pm 0.03$ & $0.23 \pm 0.04$ & $0.48 \pm 0.05$ & $0.41 \pm 0.04$ \\
\hline Textural class & - & Sandy loam & Silty clay & Silty clay & Sandy loam & Sandy loam & Silty clay \\
\hline Available N & $\mathrm{kg} \mathrm{ha}^{-1}$ & $265.1 \pm 0.13$ & $321.7 \pm 0.11$ & $285.2 \pm 0.09$ & $143.1 \pm 0.12$ & $210.7 \pm 0.08$ & $253.4 \pm 0.10$ \\
\hline Available P & $\mathrm{kg} \mathrm{ha}^{-1}$ & $23.4 \pm 0.08$ & $31.5 \pm 0.07$ & $29.5 \pm 0.07$ & $11.5 \pm 0.08$ & $15.4 \pm 0.10$ & $21.6 \pm 0.09$ \\
\hline Available K & $\mathrm{kg} \mathrm{ha}^{-1}$ & $224.5 \pm 0.10$ & $251.9 \pm 0.11$ & $210.3 \pm 0.09$ & $183.4 \pm 0.06$ & $217.1 \pm 0.07$ & $252.6 \pm 0.10$ \\
\hline Available As & $\mathrm{kg} \mathrm{ha}^{-1}$ & ND & $2.56 \pm 0.13$ & $1.73 \pm 0.14$ & ND & ND & $1.71 \pm 0.13$ \\
\hline Total As & $\mathrm{kg} \mathrm{ha}^{-1}$ & $1.26 \pm 0.11$ & $5.82 \pm 0.13$ & $4.51 \pm 0.09$ & $0.81 \pm 0.13$ & $1.07 \pm 0.10$ & $3.21 \pm 0.07$ \\
\hline Am-Fe oxides & $\mathrm{g} \mathrm{kg}^{-1}$ & $2.43 \pm 0.06$ & $2.71 \pm 0.07$ & $3.67 \pm 0.04$ & $4.16 \pm 0.09$ & $3.88 \pm 0.11$ & $4.03 \pm 0.13$ \\
\hline Am-Mn oxides & $\mathrm{g} \mathrm{kg}^{-1}$ & $0.56 \pm 0.09$ & $0.69 \pm 0.04$ & $0.83 \pm 0.11$ & $1.24 \pm 0.12$ & $1.07 \pm 0.08$ & $1.12 \pm 0.06$ \\
\hline
\end{tabular}

$O C$ organic carbon, $N$ nitrogen, $P$ phosphorus, $K$ potassium, $A s$ arsenic, $A m-F e$ amorphous iron, $A m-M n$ Amorphous manganese, $N D$ not detected. $\mathrm{S}_{1}$ to $\mathrm{S}_{5}$ indicate the name of the farms as follows: $S_{1}$ BAU, $S_{2}$ Mamalkha, $S_{3}$ Ghogha, $S_{4}$ Amarpur, $S_{5}$ Tarapur, $S_{6}$ Ekchari 
from each pot and mixed thoroughly and processed for further analysis in the laboratory. Post-harvest soil were analysed for $\mathrm{pH}$, organic carbon and extractable As (six extractants).

\subsection{Instrumentation and Analytical Conditions}

Aliquot from different extraction procedures and digested plant samples were analysed for As in AAS (Agilent 240 FS with VGA 77) at a wavelength of $193.7 \mathrm{~nm}$. Two reagents blank and one sample prepared from reference material of rice were used in every set of 30 samples. The reference material used was SRM1568a as prepared by the National Institute of Standards and Technology (NIST). The certified value of the reference material is $290 \pm 30 \mu \mathrm{g} \mathrm{kg}^{-1}$. The reference material was analysed thrice, and the As recovery was observed to be $286 \pm 18.4 \mu \mathrm{g} \mathrm{kg}^{-1}$. Precipitation of EDTA was observed during sample preparation after addition of $\mathrm{HCl}$, when $0.5(\mathrm{M})$ EDTA was used as an extractant. For analysis of plant available As as extracted by 0.5 (M) EDTA, Agilent GTA 120 Graphite Furnace atomic absorption spectrophotometer was used.

\subsection{Prediction of As Content in Rice Grain}

For prediction of As content in rice grain, FIAM was used (Datta and Young, 2005) with the assumption that uptake of As is governed by the activity of As in soil solution. Free ion activity of As in soil solution was predicted by $\mathrm{pH}$-dependent Freundlich equation as proposed by Jopony and Young (1994). This $\mathrm{pH}$-dependent Freundlich equation predicts the free ion activity in soil solution from labile soil metalloid content and $\mathrm{pH}$ with the simplifying assumption that the whole amount of metalloid is adsorbed on humus. In the present study, extractable As (six extractants) were used as estimates of labile pool of metalloid. The details of the derivation of the model equation are available in Golui et al. (2014) and Mandal et al. (2019a). The final equation for the model is as follows:

$p\left[M_{\text {plant }}\right]=C+\beta_{1} p[M c]+\beta_{2} p H$

where $C$ is the coefficient for As and $\beta_{1}$ and $\beta_{2}$ are the plant-specific constants.

\subsection{Risk Assessment}

The hazard quotient (HQ) was calculated following the protocol outlined by (Mandal et al., 2019a). For an adult, the HQ is calculated as

$$
H Q=\frac{M_{\text {plant }} \times W}{R_{f} D \times 68}
$$

where $\mathrm{M}_{\text {plant }}$ is the As content $\left(\mathrm{mg} \mathrm{kg}^{-1}\right)$ in rice grain and $\mathrm{W}$ is the amount of daily intake of rice $\left(200 \mathrm{~g} \mathrm{day}^{-1}\right)$ for an adult having a body weight of $68 \mathrm{~kg}$ (Rahman et al., 2013). The $\mathrm{R}_{\mathrm{f}} \mathrm{D}$, reference dose is $2.1 \mu \mathrm{g}$ As kg body weight ${ }^{-1}$ day $^{-1}$ (WHO, 1996). The critical value of HQ was considered as 0.5 .

\subsection{Statistical Analysis}

For statistical analysis, Microsoft Excel 2010 with "SOLVER" feature (Microsoft Corporation, USA) and SPSS window version 16.0140 (SPSS Inc., Chicago, USA) were used.

\section{Results and Discussion}

\subsection{Characterization of the Soils Subjected to Pot Experiment}

The physicochemical characteristics of the experimental soil have been depicted in Table 1. Soil $\mathrm{pH}$ ranged from 6.40 to 7.76 and $\mathrm{OC}$ from 0.23 to 0.66 ; textural class was silty clay and sandy loam. The available $\mathrm{N}$ ranged from 143.1 to $321.7 \mathrm{~kg} \mathrm{ha}^{-1}$, available $\mathrm{P}$ from 11.5 to $31.5 \mathrm{~kg} \mathrm{ha}^{-1}$ and available $\mathrm{K}$ from 183.4 to $252.6 \mathrm{~kg} \mathrm{ha}^{-1}$. In case of available As, some soils were found to be As free, whereas the highest was recorded as $2.56 \mathrm{~kg} \mathrm{ha}^{-1}$. The total As in soil ranged from 0.81 to $5.82 \mathrm{~kg} \mathrm{ha}^{-1}$. The amorphous $\mathrm{Fe}$ oxides ranged from 2.43 to $4.16 \mathrm{~g} \mathrm{~kg}^{-1}$, and the $\mathrm{Mn}$ oxides ranged from 0.56 to $1.24 \mathrm{~g} \mathrm{~kg}^{-1}$. Hence, the soils considered for experimentation were found to have wide variation in physicochemical properties. The soil acts as a sink for As, and different fractions of the soil act as the binding sites for As and herein lie the justification 
of using soils of diverse properties for experimentation as reported by Giri et al. (2012).

\subsection{Recoveries by the Different Extractants}

A comparative study of recoveries of plant available As of the treated pots by the different extractants revealed that $0.2(\mathrm{M}) \mathrm{NH}_{4}$-oxalate has the highest recovery of $2769.8 \pm 219.20 \mu \mathrm{g} \mathrm{kg}^{-1}$. This extractant mainly targets the As that is co-precipitated and bound with amorphous $\mathrm{Fe}, \mathrm{Al}$ and $\mathrm{Mn}$ oxides. Given that the soils under experimentation have amorphous $\mathrm{Fe}, \mathrm{Al}$ and $\mathrm{Mn}$ oxides, the probability of co-precipitation of As with these fractions in the soil remained high, and hence higher recovery was observed by $0.2(\mathrm{M}) \mathrm{NH}_{4}$-oxalate. The possible mechanism of extraction may be complexation promoted by the ligand followed by dissolution of $\mathrm{Fe}, \mathrm{Al}$ and $\mathrm{Mn}$ oxyhydroxide (Keon et al., 2001). Recovery efficiency was highest for 0.2 (M) $\mathrm{NH}_{4}$-oxalate followed by $0.05(\mathrm{~N}) \mathrm{HCl}+0.025(\mathrm{~N})$ $\mathrm{H}_{2} \mathrm{SO}_{4}, \quad 1927.0 \pm 195.27 \mu \mathrm{g} \mathrm{kg} \mathrm{kg}^{-1}$, which mainly extracts by acidic dissolution from the clay lattices. Similar trend of extraction was reported by Giri et al. (2012). The next recovery efficiency was for 0.5 (M) $\mathrm{KH}_{2} \mathrm{PO}_{4}, 976.5 \pm 87.03 \mu \mathrm{g} \mathrm{kg}{ }^{-1}$, which mainly targets the strongly adsorbed As by anion exchange of $\mathrm{PO}_{4}{ }^{3-}$ for $\mathrm{AsO}_{4}{ }^{3-}$ and $\mathrm{AsO}_{3}{ }^{3-}$ (Keon et al., 2001). The mobilization of $\mathrm{AsO}_{4}{ }^{3-}$ and $\mathrm{AsO}_{3}{ }^{3-}$ may also be due to ligand exchange mechanism by $\mathrm{PO}_{4}{ }^{3-}$ (Alam et al., 2018). The next efficient extractant was 0.5 (M) $\mathrm{NaHCO}_{3}, 772.7 \pm 81.63 \mu \mathrm{g} \mathrm{kg} \mathrm{kg}^{-1}$, followed by $0.5(\mathrm{~N}) \mathrm{NH}_{4} \mathrm{~F}, 539.8 \pm 65.66 \mu \mathrm{g} \mathrm{kg}^{-1}$. Both these extractants recover $\mathrm{As}$ bound to the $\mathrm{Ca}, \mathrm{Fe}$ and $\mathrm{Al}$ through their dissolution. Among all the extractants, 0.5 (M) EDTA, $253.1 \pm 28.84 \mu \mathrm{g} \mathrm{kg}^{-1}$, has the least recovery efficiency, which possibly recovers As from the adsorbed phase by chelation. In summary, the order of recoveries by the extractants is as follows: 0.2 (M) $\mathrm{NH}_{4}$-oxalate $>0.05$ (N) $\mathrm{HCl}+0.025$ (N) $\mathrm{H}_{2} \mathrm{SO}_{4}>0.5(\mathrm{M}) \mathrm{KH}_{2} \mathrm{PO}_{4}>0.5(\mathrm{~N}) \mathrm{NH}_{4} \mathrm{~F}>0.5(\mathrm{M})$ $\mathrm{NaHCO}_{3}>0.5(\mathrm{M})$ EDTA.

\subsection{Precipitation of EDTA During Sample Preparation}

Plant available As cannot be determined by AAS coupled with VGA when 0.5 (M) EDTA was used as an extractant. A precipitation of EDTA was observed during sample preparation after addition of $\mathrm{HCl}$ when $0.5(\mathrm{M})$ EDTA was used as an extractant. The reason for precipitation of EDTA can be due to the addition of $10 \% \mathrm{HCl}$, which reduced the $\mathrm{pH}$ of the solution to 2.72 (Supplementary Table S3). Golui et al. (2018) also reported that critical concentration of $\mathrm{HNO}_{3}$ in EDTA solution is $0.075 \%$, beyond which precipitation occurred. Due to the covalent bonding of hydrogen in EDTA, the carboxyl groups remain undissociated having no charge which makes EDTA almost insoluble in water. With the rise of $\mathrm{pH}$, the carboxyl (COO-) starts dissociating (pKa values are 2.0, 2.7, 6.2, and 10.3 , respectively) releasing proton $\left(\mathrm{H}^{+}\right)$to the solution, making EDTA water soluble (Vogel \& Svehla, 1996). With the addition of $\mathrm{HCl}$, the $\mathrm{pH}$ is reduced, and hence the precipitation of EDTA takes place.

\subsection{Relationship Between Plant Available As by Different Extractants and the Soil Properties}

Correlations studies were undertaken between the amount of As $\left(\mathrm{mg} \mathrm{kg}^{-1}\right)$ recovered by different extraction methodologies and the common physicochemical properties of the soils as depicted in Table 2. The soil organic carbon (OC), clay and cation exchange capacity (CEC) expressed a negative correlation with the extractable As by different extractants. Significant negative correlation with $\mathrm{OC}$ was observed with respect to 0.5 (M) $\mathrm{NaHCO}_{3}$ $\left(\mathrm{r}=-0.915^{* *}\right), 0.5 \quad(\mathrm{M}) \mathrm{KH}_{2} \mathrm{PO}_{4} \quad\left(\mathrm{r}=-0.938^{* *}\right)$ and $0.5(\mathrm{M})$ EDTA $(\mathrm{r}=-0.902 * *)$; with clay, it was observed with respect to 0.5 (M) $\mathrm{NaHCO}_{3}$ $\left(\mathrm{r}=-0.826^{*}\right), 0.5(\mathrm{M}) \mathrm{KH}_{2} \mathrm{PO}_{4}\left(\mathrm{r}=-0.881^{*}\right)$ and $0.2(\mathrm{M}) \mathrm{NH}_{4}$-oxalate $\left(\mathrm{r}=-0.801^{*}\right)$ and with $\mathrm{CEC}$, it was observed with respect to 0.5 (M) $\mathrm{NaHCO}_{3}$ $\left(\mathrm{r}=-0.904^{* *}\right), 0.5(\mathrm{M}) \mathrm{KH}_{2} \mathrm{PO}_{4}\left(\mathrm{r}=-0.935^{* *}\right)$ and 0.5 (M) EDTA $\left(\mathrm{r}=-0.839^{* *}\right)$. Negative correlations with available $\mathrm{K}$ and $\mathrm{P}$ were recorded with plant available As extracted by different extraction methodologies; however, the correlation was significant with respect to available $\mathrm{P}$ except $0.5(\mathrm{~N}) \mathrm{NH}_{4} \mathrm{~F}$. For available $\mathrm{N}$, positive correlation was observed with $0.5(\mathrm{M}) \mathrm{NaHCO}_{3}$ and $0.5(\mathrm{~N}) \mathrm{NH}_{4} \mathrm{~F}$, and negative correlations were observed with respect to all other extractants. However, the correlations were found to be non-significant. A positive significant correlation was observed between available and total As with all the extraction methodologies except $0.5(\mathrm{~N}) \mathrm{NH}_{4} \mathrm{~F}$ and $0.2(\mathrm{M}) \mathrm{NH}_{4}$-oxalate. Negative non-significant 
Table 2 Correlation coefficient (r) between extractable arsenic and soil physicochemical properties

\begin{tabular}{lllllllllll}
\hline Parameters & OC $\%$ & $p H$ & CEC & Clay & Aval K & Avl P & Avl N & Total As & Am-Fe & Am-Mn \\
\hline $0.5(\mathrm{M}) \mathrm{NaHCO}_{3}$ & $-0.915^{* *}$ & $0.875^{*}$ & $-0.904^{* *}$ & $-0.826^{*}$ & -0.070 & $-0.914^{* *}$ & 0.391 & $0.911^{* *}$ & -0.543 & -0.232 \\
$0.5(\mathrm{~N}) \mathrm{NH}_{4} \mathrm{~F}$ & -0.752 & $0.751^{*}$ & -0.727 & -0.816 & -0.414 & -0.824 & 0.031 & 0.743 & -0.410 & -0.213 \\
$0.5(\mathrm{M}) \mathrm{KH}_{2} \mathrm{PO}_{4}$ & $-0.938^{* *}$ & $0.893^{*}$ & $-0.935^{*}$ & $-0.881^{*}$ & -0.097 & $-0.974^{*}$ & -0.058 & $0.931^{* *}$ & -0.556 & -0.278 \\
$0.05(\mathrm{~N}) \mathrm{HCl}_{+} 0.025\left(\mathrm{~N}_{2} \mathrm{H}_{2} \mathrm{SO}_{4}\right.$ & -0.711 & 0.683 & -0.822 & -0.711 & -0.279 & $-0.899^{*}$ & -0.042 & $0.834^{*}$ & -0.012 & -0.114 \\
$0.2(\mathrm{M}) \mathrm{NH}_{4} \mathrm{oxalate}$ & -0.673 & 0.568 & $-0.839^{*}$ & -0.733 & -0.204 & $-0.906^{*}$ & -0.028 & 0.720 & -0.576 & -0.313 \\
$0.5(\mathrm{M}) \mathrm{EDTA}$ & $-0.902^{* *}$ & $0.863^{*}$ & -0.832 & $-0.801^{*}$ & -0.083 & $-0.898^{*}$ & -0.421 & $0.925^{* *}$ & -0.432 & -0.329 \\
\hline
\end{tabular}

${ }^{* * *}$ Significant at $p<0.01$

*Significant at $p<0.05$

$O C$ organic carbon, $C E C$ cation exchange capacity, $N$ nitrogen, $P$ phosphorus, $K$ potassium, $A s$ arsenic, $A m-F e$ amorphous iron, $A m$ $\mathrm{Mn}$ amorphous manganese

correlation was observed between amorphous $\mathrm{Fe}$ and $\mathrm{Mn}$ oxides and available As with respect to all the extraction methodologies except $0.05(\mathrm{~N})$ $\mathrm{HCl}+0.025(\mathrm{~N}) \mathrm{H}_{2} \mathrm{SO}_{4}$. The significant negative correlations of OC, clay and CEC with soil As extracted by different extractants indicate a decrease in extractable or bioavailable soil As. Organic matter can compete with As for sorption sites due to the presence of humic acid which binds As and dissolved organic matter can also reduce the sorption of As to soil particles through redox reaction and also forming soluble complexes with As (Kumar et al., 2021; Mahimairaja et al., 2005; Mandal et al., 2019a, b). The positive correlation of available As with $\mathrm{pH}$ is due to decrease in arsenate $\left(\mathrm{As}^{5+}\right)$ adsorption with increasing $\mathrm{pH}$, particularly above $\mathrm{pH} 8.5$, while the opposite occurs for arsenite $\left(\mathrm{As}^{3+}\right)$ (Giri et al., 2012). Again, under direct seeded rice, dominance of $\mathrm{As}^{5+}$ was more as compared to that of $\mathrm{As}^{3+}$. Due to the structural similarity of phosphate with $\mathrm{As}^{5+}$, competition for sorption sites can be another key factor in the observed behaviour of As in the soils (Lambkin \& Alloway, 2003). The addition of phosphate to the soils increases the mobility and bioavailability of As, which can be attributed to the observed significant negative correlation between extractable soil As and available soil P. The amorphous $\mathrm{Fe}$ and $\mathrm{Mn}$ oxides (Am-Fe and $\mathrm{Mn}$ ) act as sorbent for both the arsenite and arsenate ions, which supports the observed negative correlations of Am-Fe and $\mathrm{Mn}$ oxides with the extractable As. The Am-Fe and $\mathrm{Mn}$ oxides involve As to form inner sphere surface complex with the displacement of $\mathrm{OH}^{-}$and $\mathrm{H}_{2} \mathrm{O}$ as a ligand substitution transfer of electron from As, which results in the release of $\mathrm{Fe}$ and $\mathrm{Mn}$ within the soil solution. The $\mathrm{As}^{5+}$ and $\mathrm{As}^{3+}$ species of As also undergoes $\mathrm{pH}$-induced adsorption and co-precipitation with Fe-oxyhydroxide, most notably ferrihydrite $(\beta-\mathrm{FeOOH})$, lepidocrocite $(\gamma-\mathrm{FeOOH})$, goethite $(\alpha-\mathrm{FeOOH})$ and haematite $\left(\mathrm{Fe}_{2} \mathrm{O}_{3}\right)$ (Aide et al., 2016).

The plant available As determined by different extractants and soil physicochemical properties were subjected to stepwise multiple regression to achieve the best model equation as has been depicted in Supplementary Table $\mathrm{S} 4$. The $\mathrm{R}^{2}$ values revealed that 0.5 (M) $\mathrm{KH}_{2} \mathrm{PO}_{4}$ have the highest regression coefficient $\left(\mathrm{R}^{2}=0.84\right)$ with respect to the soil properties (CEC, clay content, available $\mathrm{K}, \mathrm{P}$, total $\mathrm{As}$ and $\mathrm{Fe}$ oxide) concerned followed by $0.5(\mathrm{M}) \mathrm{NaHCO}_{3}\left(\mathrm{R}^{2}=0.82\right)$, $0.5(\mathrm{~N}) \mathrm{NH}_{4} \mathrm{~F}\left(\mathrm{R}^{2}=0.79\right), 0.5(\mathrm{M})$ EDTA $\left(\mathrm{R}^{2}=0.78\right)$, 0.2 (M) $\mathrm{NH}_{4}$-oxalate $\left(\mathrm{R}^{2}=0.77\right)$ and $0.05(\mathrm{~N})$ $\mathrm{HCl}+0.025(\mathrm{~N}) \mathrm{H}_{2} \mathrm{SO}_{4}\left(\mathrm{R}^{2}=0.74\right)$. Stepwise regression essentially does multiple regressions a number of times, each time removing the weakest correlated variable. Across the extractant, soil properties like CEC, clay content, available $\mathrm{P}, \mathrm{K}$, total As and Fe and Mn oxides have been identified as determining factors governing the availability of extractable As in soil in either way. Since As and P are both placed in group $\mathrm{Vb}$ of the periodic table, the interaction of As and $\mathrm{P}$ in soil-plant system is an important issue in respect of As mobilization. The reduction in arsenate adsorption was due to the competitive effects of arsenate on phosphate adsorption by soil minerals, although a large variation in the degree of competition between these two oxyanions has been reported by Mukhopadhyay (2002). There have been both direct and indirect evidence to suggest that As is held in soils and sediments by oxides (e.g. Fe, Al, Mn) 
through the formation of inner-sphere complexes via ligand exchange mechanism (Majumdar \& Sanyal, 2003), and hence, the amorphous Fe and Mn oxides regulate the availability of As (Zheng et al., 2020). Mobility of As in the soil during the flooded period (rice cultivation) was controlled by the setting of oxic/anoxic interfaces at the surface of soil in contact with flooding water and in the rhizosphere of rice as reported by Roy et al. (2018, 2020). The relationship of plant available As with soil properties like CEC, $\mathrm{P}$, clay content and total As has been previously reported by Giri et al. (2012).

\subsection{Relationship Among Different Extractants and Crop Uptake}

All the extractants were significantly correlated with each other (Table 3). Strong correlations were obtained between $0.5(\mathrm{M}) \mathrm{NaHCO}_{3}$ and $0.5(\mathrm{M})$ $\mathrm{KH}_{2} \mathrm{PO}_{4}(\mathrm{r}=0.937 * *), 0.05 \quad(\mathrm{~N}) \mathrm{HCl}+0.025 \quad(\mathrm{~N})$ $\mathrm{H}_{2} \mathrm{SO}_{4}$ and $0.5(\mathrm{M}) \mathrm{NaHCO}_{3}(\mathrm{r}=0.932 * *)$ and also between $0.5(\mathrm{M}) \mathrm{KH}_{2} \mathrm{PO}_{4}$ and $0.05(\mathrm{~N}) \mathrm{HCl}+0.025$ (N) $\mathrm{H}_{2} \mathrm{SO}_{4}\left(\mathrm{r}=0.936^{* *}\right)$. This significant positive correlation may be ascribed to the fact that both the extractants were able to recover As more or less from the similar pools. The above findings are in accordance with the results observed by Giri et al. (2012). By taking a look at the correlation of the available As extracted by the different methodologies with the crop uptake, it was observed that $0.5(\mathrm{M}) \mathrm{KH}_{2} \mathrm{PO}_{4}$ has the highest correlation in comparison with the other extractants. The reason for $0.5(\mathrm{M}) \mathrm{KH}_{2} \mathrm{PO}_{4}$ having the best correlation with the different soil properties as well as crop uptake in the experimentation may be due to the fact that it is able to recover the exchangeable, as well as water soluble, and also the specifically sorbed As as compared to the other extractant used (Datta et al., 2018).

\subsection{As Content in Rice Plant Parts}

As content in root, straw, leaf and grain increased significantly with increase in As dose irrespective of the soil types as can be observed from Fig. 1. Regardless of the As dose, the tissue concentration in rice trailed the order of root $>$ straw $>$ leaf and grain. The root concentration ranged from $0 \mathrm{mg} \mathrm{kg}^{-1}$ (uncontaminated soils) and $53.35 \mathrm{mg} \mathrm{kg}^{-1}$ at $\mathrm{As}_{0}$ to $216.73 \mathrm{mg} \mathrm{kg}^{-1}$ at $\mathrm{As}_{80}$. Lowest As concentration in straw was $0 \mathrm{mg} \mathrm{kg}^{-1}$ (uncontaminated soils) and $7.42 \mathrm{mg} \mathrm{kg}^{-1}$ at $\mathrm{As}_{0}$ to $67.86 \mathrm{mg} \mathrm{kg}^{-1}$ at $\mathrm{As}_{80}$. In leaf, the minimum grain concentration was recorded as $0 \mathrm{mg} \mathrm{kg}^{-1}$ (uncontaminated soils) and $1.35 \mathrm{mg} \mathrm{kg}^{-1}$ at $\mathrm{As}_{0}$ to $38.63 \mathrm{mg} \mathrm{kg}^{-1}$ at $\mathrm{As}_{80}$. The grain As concentration was observed to be $0 \mathrm{mg} \mathrm{kg}^{-1}$ (uncontaminated soils) and $0.11 \mathrm{mg} \mathrm{kg}^{-1}$ at $\mathrm{As}_{0}$ to $0.65 \mathrm{mg} \mathrm{kg}^{-1}$ at $\mathrm{As}_{80}$. The surge in the As build-up in the plant parts is mainly attributed to the exposure of plant roots to the higher doses of As. The translocation and bioaccumulation factors have also played a key role which resulted in the above-mentioned trend. Abedin and Meharg (2002)reported a similar trend

Table 3 Pearson correlation between extractable arsenic and grain uptake

\begin{tabular}{|c|c|c|c|c|c|c|c|}
\hline & $0.5(\mathrm{M}) \mathrm{NaHCO}_{3}$ & $0.5(\mathrm{~N}) \mathrm{NH}_{4} \mathrm{~F}$ & $0.5(\mathrm{M}) \mathrm{KH}_{2} \mathrm{PO}_{4}$ & $\begin{array}{l}0.05(\mathrm{~N}) \mathrm{HCl}+ \\
0.025(\mathrm{~N}) \mathrm{H}_{2} \mathrm{SO}_{4}\end{array}$ & $\begin{array}{l}0.2(\mathrm{M}) \\
\mathrm{NH}_{4} \text {-oxalate }\end{array}$ & 0.5 (M) EDTA & $\begin{array}{l}\text { Grain } \\
\text { uptake }\end{array}$ \\
\hline $0.5(\mathrm{M}) \mathrm{NaHCO}_{3}$ & 1 & & & & & & \\
\hline $0.5(\mathrm{~N}) \mathrm{NH}_{4} \mathrm{~F}$ & $0.692 *$ & 1 & & & & & \\
\hline $0.5(\mathrm{M}) \mathrm{KH}_{2} \mathrm{PO}_{4}$ & $0.937^{* *}$ & 0.580 & 1 & & & & \\
\hline $\begin{array}{l}0.05(\mathrm{~N}) \mathrm{HCl}+ \\
0.025(\mathrm{~N}) \mathrm{H}_{2} \mathrm{SO}_{4}\end{array}$ & $0.932 * *$ & $0.777 * *$ & $0.936^{* *}$ & 1 & & & \\
\hline $0.2(\mathrm{M}) \mathrm{NH}_{4}$-oxalate & $0.867^{* *}$ & $0.921^{* *}$ & $0.826^{* *}$ & $0.940 * *$ & 1 & & \\
\hline $0.5(\mathrm{M})$ EDTA & $0.875^{* *}$ & 0.610 & $0.849 * *$ & $0.842 * *$ & 0.731 & 1 & \\
\hline Grain uptake & $0.872 * *$ & $0.744 *$ & $0.897 * *$ & $0.851 * *$ & $0.701 *$ & $0.721 *$ & 1 \\
\hline
\end{tabular}

${ }^{* * *}$ Significant at $p<0.01$

* Significant at $p<0.05$

$\mathrm{NaHCO}_{3}$ sodium bi-carbonate, $\mathrm{NH}_{4} \mathrm{~F}$ ammonium fluoride, $\mathrm{HCl}$ hydrochloric acid, $\mathrm{H}_{2} \mathrm{SO}_{4}$ sulphuric acid, $\mathrm{NH}_{4}$-oxalate ammonium oxalate, EDTA ethylene di-amine tetra acetic acid 
A

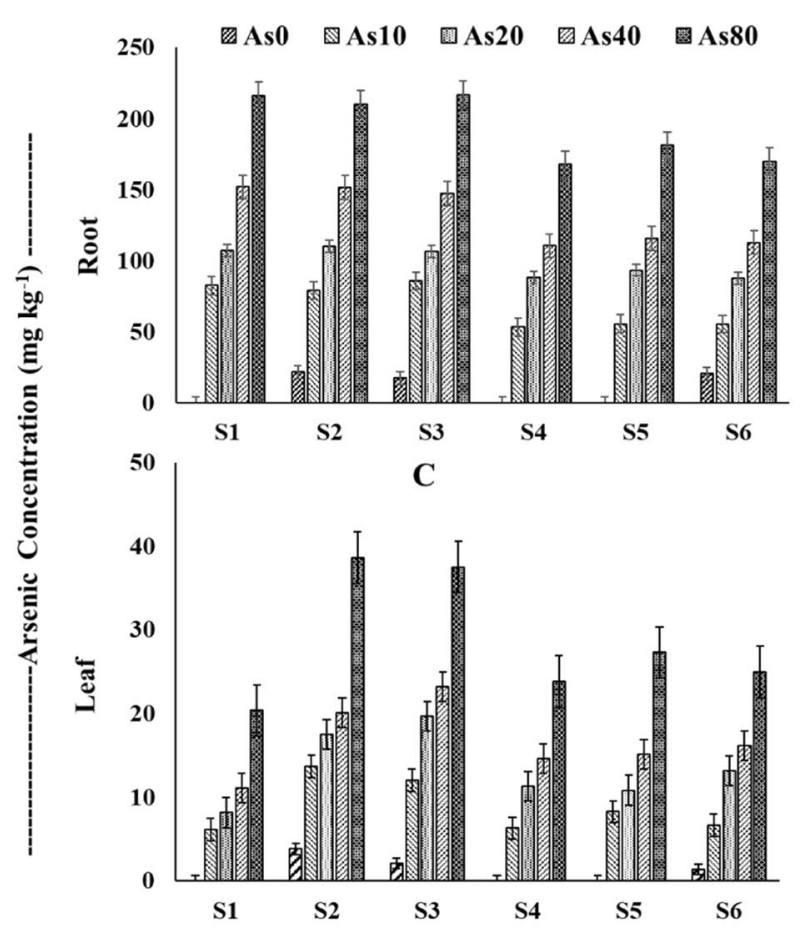

B
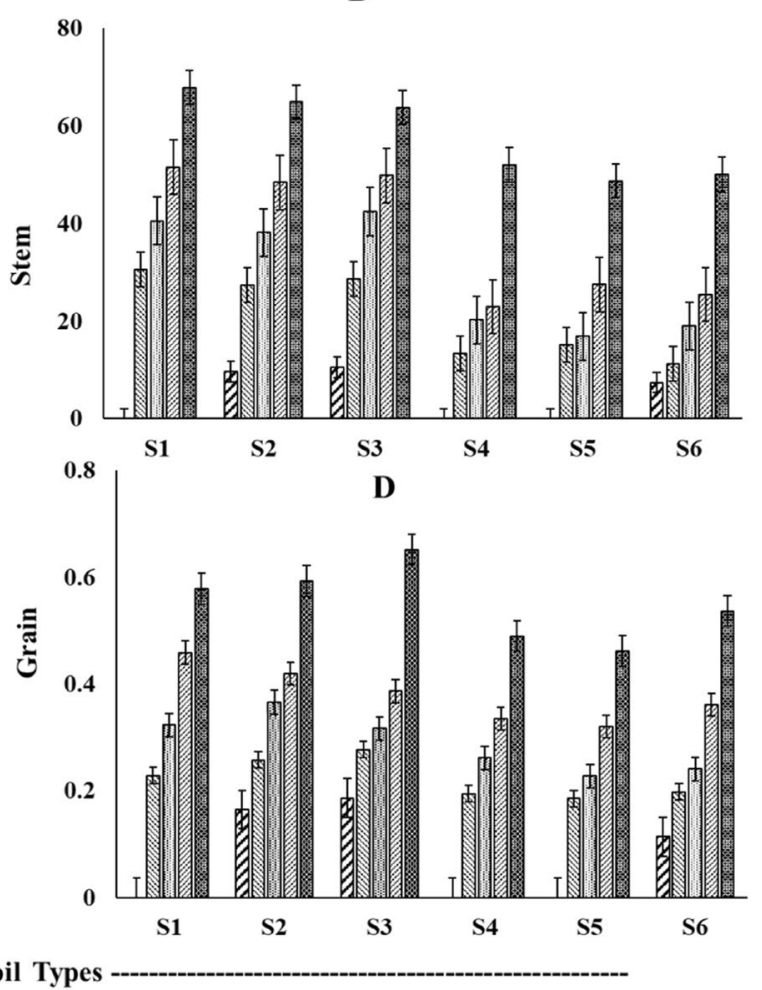

Fig. 1 Effect of average ( \pm SE) doses of arsenic on accumulation of arsenic in $\mathbf{A}$ root, $\mathbf{B}$ stem, $\mathbf{C}$ leaf and $\mathbf{D}$ grain. Notes: S1 to S5 indicate the name of the farms as follows: S1 BAU, S2 Mamalkha, S3 Ghogha, S4 Amarpur, S5 Tarapur, S6 Ekchari

of root $>$ straw $>$ husk $>$ grain as was also reported by Das et al. (2013). An increased bioaccumulation or build-up of As during plant growth stages and on the other hand a reduction in translocation within the plant system have led to the above trend of As accumulation (Huq et al., 2011).

\subsection{Predictability of FIAM, Suitability of Extractant and Risk Assessment}

The model parameters $\left(\mathrm{C}, \beta_{1}\right.$ and $\left.\beta_{2}\right)$, which is crop specific along with prediction coefficient $\left(\mathrm{R}^{2}\right)$ can be visualized in Table 4 . The $\mathrm{pH}$ and organic carbon (Supplementary Table S5) were used as input variable to the solubility-FIAM along with plant available As by different extractants and grain As concentration. The prediction coefficient of the model with respect to extractable As using different extractants followed the order of $0.5(\mathrm{M})$ EDTA $\left(\mathrm{R}^{2}=0.9036\right)<0.2(\mathrm{M})$ $\mathrm{NH}_{4}$-oxalate $\left(\mathrm{R}^{2}=0.9108\right)<0.05 \quad(\mathrm{~N}) \quad \mathrm{HCl}+0.025$ (N) $\mathrm{H}_{2} \mathrm{SO}_{4} \quad\left(\mathrm{R}^{2}=0.9237\right)<0.5 \quad$ (N) $\mathrm{NH}_{4} \mathrm{~F}$
$\left(\mathrm{R}^{2}=0.9274\right)<0.5(\mathrm{M}) \mathrm{NaHCO}_{3}\left(\mathrm{R}^{2}=0.9287\right)<0.5$ (M) $\mathrm{KH}_{2} \mathrm{PO}_{4}\left(\mathrm{R}^{2}=0.9356\right)$. Given that $0.5(\mathrm{M})$ $\mathrm{KH}_{2} \mathrm{PO}_{4}$ is having an edge over the other extractants, it can be used as a suitable extractant for determination of plant available As besides the traditional 0.5 (M) $\mathrm{NaHCO}_{3}$.

The HQ values indicated that rice grain will prompt health threat to humans when HQ $>0.5$ as can be observed in Fig. 2. When the levels of As dose were above $\mathrm{As}_{20}$, the HQ was found to be greater than 0.5 in soil type $S_{2}$, and at $A_{40}$ it was observed in soil types $S_{1}$ and $S_{3}$. The HQ crossed the critical range of 0.5 in soils under acidic range $\left(\mathrm{S}_{4}, \mathrm{~S}_{5}\right.$, and $\left.\mathrm{S}_{6}\right)$ at $\mathrm{As}_{80}$. The reason for having a lower HQ between $\mathrm{As}_{10}$ and $\mathrm{As}_{40}$ may be attributed to the fact that those soils bearing a lower range of $\mathrm{pH}$ also have high amount of amorphous Fe and Mn oxides, which helped in the occlusion of As and hence reduced its bioavailability. As $0.5(\mathrm{M}) \mathrm{KH}_{2} \mathrm{PO}_{4}$ proved to be the suitable extractant, we also compared observed and predicted HQ across the different soil types (Supplementary 
Table 4 Model parameters for predicting uptake of arsenic grain by rice as a function of $\mathrm{pH}$, organic carbon and extractable arsenic

\begin{tabular}{lllll}
\hline Extractant & \multicolumn{2}{l}{ Model parameters } & & \\
\cline { 2 - 5 } & $\mathrm{C}$ & $\beta_{1}$ & $\beta_{2}$ & 0.786996 \\
\hline $0.5(\mathrm{M}) \mathrm{NaHCO}_{3}$ & -1.0648 & -0.0826 & 0.581538 & 0.9287 \\
$0.5(\mathrm{~N}) \mathrm{NH}_{4} \mathrm{~F}$ & -1.8273 & -0.0628 & 0.745952 & 0.9274 \\
$0.5(\mathrm{M}) \mathrm{KH}_{2} \mathrm{PO}_{4}$ & -0.8378 & -0.1242 & 0.575817 & 0.9356 \\
$0.05(\mathrm{~N}) \mathrm{HCl}^{2} 0.025\left(\mathrm{~N}_{2} \mathrm{H}_{2} \mathrm{SO}_{4}\right.$ & -1.0861 & -0.1562 & 0.770103 & 0.9237 \\
$0.2(\mathrm{M}) \mathrm{NH}_{4}$-oxalate & -1.3963 & -0.0877 & 0.885707 & 0.9036 \\
$0.5(\mathrm{M})$ EDTA & -0.5441 & -0.1642 & 0.9108 \\
\hline
\end{tabular}

$\mathrm{NaHCO}_{3}$ sodium bi-carbonate, $\mathrm{NH}_{4} \mathrm{~F}$ ammonium fluoride, $\mathrm{HCl}$ hydrochloric acid, $\mathrm{H}_{2} \mathrm{SO}_{4}$ sulphuric acid, $\mathrm{NH}_{4}$-oxalate ammonium oxalate, EDTA ethylene di-amine tetra acetic acid

Fig. S1). The close agreement of the measured values with the model predicted values supports the idea that FIAM can be used successfully as a tool for predicting the risk.

\section{Conclusions}

We observed that all measured soil physicochemical properties except available N, K and amorphous $\mathrm{Fe}$ and $\mathrm{Mn}$ oxides have a significant correlation with the As extracted using under different methods of extraction. Among the six extractants used, $0.5(\mathrm{M}) \mathrm{KH}_{2} \mathrm{PO}_{4}$ and $0.5(\mathrm{M}) \mathrm{NaHCO}_{3}$ gave the best correlation with the soil properties and crop uptake. The predictability of solubility
FIAM in terms of As content in rice grain also supported the fact that $94 \%$ variation of As content in rice grain can be explained when $0.5(\mathrm{M})$ $\mathrm{KH}_{2} \mathrm{PO}_{4}$ is used as an extractant for determination of plant available As. Although 0.5 (M) $\mathrm{NaHCO}_{3}$ at $\mathrm{pH} 8.5$ is widely used as an extractant of extractable As, our findings indicated that $0.5(\mathrm{M}) \mathrm{KH}_{2} \mathrm{PO}_{4}$ can also be used as an extractant as it has an edge over other extractants in terms of significant correlation with the soil parameters for the As contaminated areas of the IndoGangetic Plain. Lastly, our findings also suggest that $0.5(\mathrm{M})$ EDTA cannot be used as an extractant for determination of available As using AAS coupled with VGA.
Fig. 2 Hazard quotient for average $( \pm S E)$ intake of arsenic by human through consumption. Notes: S1 to S5 indicate the name of the farms as follows: $S 1$ BAU, S2 Mamalkha, S3 Ghogha, S4 Amarpur, S5 Tarapur, S6 Ekchari

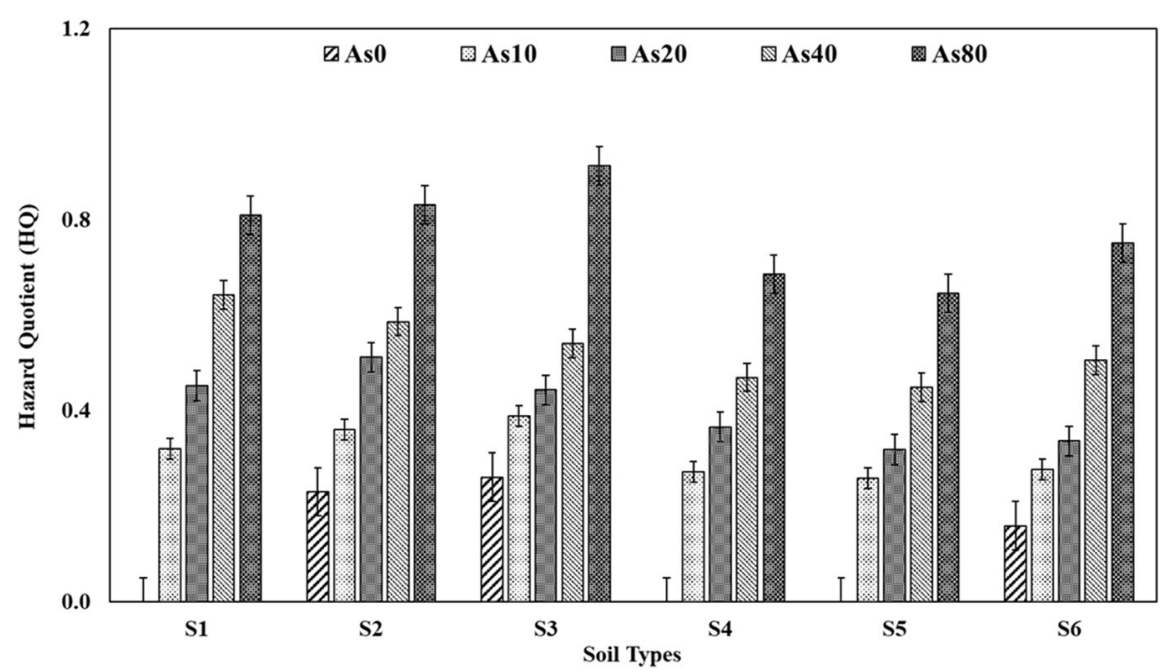


Supplementary Information The online version contains supplementary material available at https://doi. org/10.1007/s11270-021-05215-y.

Author Contribution All authors contributed significantly towards the final make-up of the paper. Expressing in terms of author initials, JM, DG and BD conceived the idea of the experiment; AR and MG carried out the experiment and DG and DS model and statistical computations; JM, AR and PBK contributed in analysis; BD and DS provided valuable feedbacks after proofreading; AR, JM, BD and PG prepared the original draft, edited and compiled the manuscript.

Funding The work was supported by the Science Engineering Research Board (SERB), Department of Science and Technology (DST), Government of India funded project, "Arsenic contamination in Bihar: Implications in agriculture and possible mitigation options".

Data Availability Data generated from the experiment.

Code Availability Not applicable.

\section{Declarations}

Conflict of Interest The authors declare no competing interests.

Open Access This article is licensed under a Creative Commons Attribution 4.0 International License, which permits use, sharing, adaptation, distribution and reproduction in any medium or format, as long as you give appropriate credit to the original author(s) and the source, provide a link to the Creative Commons licence, and indicate if changes were made. The images or other third party material in this article are included in the article's Creative Commons licence, unless indicated otherwise in a credit line to the material. If material is not included in the article's Creative Commons licence and your intended use is not permitted by statutory regulation or exceeds the permitted use, you will need to obtain permission directly from the copyright holder. To view a copy of this licence, visit http://creativecommons.org/licenses/by/4.0/.

\section{References}

Abedin, M. J., \& Meharg, A. A. (2002). Relative toxicity of arsenite and arsenate on germination and early seedling growth of rice (Oryza sativa L.). Plant and soil, 243(1), 57-66.

Aide, M., Beighley, D., \& Dunn, D. (2016). Arsenic in the soil environment: A soil chemistry. International Journal of Applied Agricultural Research, 11, 1-28.

Alam, M. A., Shaikh, W. A., Alam, M. O., Bhattacharya, T., Chakraborty, S., Show, B., \& Saha, I. (2018). Adsorption of As (III) and As (V) from aqueous solution by modified Cassia fistula (golden shower) biochar. Applied Water Science, $8(7), 1-14$.

Bouyoucos, G. J. (1962). Hydrometer method improved for making particle size analyses of soils. Agronomy Journal, $54,464-465$.
Das, I., Ghosh, K., Das, D. K., \& Sanyal, S. K. (2013). Assessment of arsenic toxicity in rice plants in areas of West Bengal. Chemical Speciation \& Bioavailability, 25(3), 201-208.

Datta, S. P., \& Young, S. D. (2005). Predicting metal uptake and risk to the human food chain from leaf vegetables grown on soils amended by long-term application of sewage sludge. Water, Air, and Soil Pollution, 163(1), 119-136.

Datta, S. P., Subba Rao, A., \& Ganeshamurthy, A. N. (1997). Effect of electrolytes coupled with variable stirring on soil $\mathrm{pH}$. Journal of the Indian Society of Soil Science, 45, 185-187.

Datta, S. P., Meena, M. C., Barman, M., Golui, D., Mishra, R., \& Shukla, A. K. (2018). Soil tests for micronutrients: Current status and future thrust. Indian Journal of Fertilisers, 14(5), 32-51.

Giri, P. K., Bhattacharyya, K., Sinha, B., \& Mazumdar, D. (2012). Study of the suitability of selected extractants for determination of plant-available arsenic in some inceptisols of West Bengal, India. Communications in Soil Science and Plant Analysis, 43(19), 2449-2466.

Golui, D., Datta, S. P., Rattan, R. K., Dwivedi, B. S., \& Meena, M. C. (2014). Predicting bioavailability of metals from sludge amended soils. Environmental Monitoring and Assessment, 186, 8541-8553.

Golui, D., Mazumder, D. G., Sanyal, S. K., Datta, S. P., Ray, P., Patra, P. K., Sarkar, S., \& Bhattacharya, K. (2017). Safe limit of arsenic in soil in relation to dietary exposure of arsenicosis patients from Malda district, West Bengal-A case study. Ecotoxicology and Environmental Safety, 144, 227-235.

Golui, D., Datta, S. P., \& Kaushik, S. C. (2018). Interferences of medium and matrix in determination of trace toxic elements using inductively coupled plasma mass spectrometry. Journal of Environmental Biology, 39, 103-108.

Huq, S.M.I., Sultana, S., Chakraborty, G., \& Chowdhury, M.T.A. (2011). A mitigation approach to alleviate arsenic accumulation in rice through balanced fertilization. Applied and Environmental Soil Science, pp 1-8.

Johnston, S. E., \& Barnard, W. M. (1979). Comparative effectiveness of fourteen solutions for extracting arsenic from four western New York soils. Soil Science Society of America Journal, 43(2), 304-308.

Jopony, M., \& Young, S. D. (1994). The solid solution equilibria of lead and cadmium in polluted soils. European Journal of Soil Science, 45, 59-70.

Keon, N. E., Swartz, C. H., Brabander, D. J., Harvey, C., \& Hemond, H. F. (2001). Validation of an arsenic sequential extraction method for evaluating mobility in sediments. Environmental Science \& Technology, 35(13), 2778-2784.

Knudsen, D., Peterson, G. A., Pratt, P. F., \& Lithium, S. (1982). Potassium. Methods of soil analysis. Chemical and microbiological properties (pp. 229-230). America Society of Agronomy and Soil Science of America Inc.

Kumar, S. N., Mishra, B. B., Kumar, S., \& Mandal, J. (2021). Organo-arsenic complexation studies explaining the reduction of uptake of arsenic in wheat grown with contaminated irrigation water and organic amendments. Water Air \& Soil Pollution, 232, 118. 
Kumari, P. B., Singh, Y. K., Mandal, J., Shambhavi, S., Sadhu, S. K., Kumar, R., Ghosh, M., Raj, A., \& Singh, M. (2021). Determination of safe limit for arsenic contaminated irrigation water using solubility free ion activity model (FIAM) and Tobit Regression Model. Chemosphere, 270, 128630.

Lambkin, D. C., \& Alloway, B. J. (2003). Arsenate-induced phosphate release from soils and its effect on plant phosphorus. Water, Air, and Soil Pollution, 144(1), 41-56.

Mahimairaja, S., Bolan, N. S., Adriano, D. C., \& Robinson, B. (2005). Arsenic contamination and its risk management in complex environmental settings. Advances in Agronomy, $86,1-82$.

Majumdar, K., \& Sanyal, S. K. (2003). pH-dependent arsenic sorption in an Alfisol and an Entisol of West Bengal. Agropedology, 13, 25-29.

Mandal, J., Golui, D., \& Datta, S. P. (2019a). Assessing equilibria of organo-arsenic complexes and predicting uptake of arsenic by wheat grain from organic matter amended soils. Chemosphere, 234, 419-426.

Mandal, J., Golui, D., Raj, A., \& Ganguly, P. (2019b). Risk assessment of arsenic in wheat and maize grown in organic matter amended soils of Indo-Gangetic plain of Bihar, India. Soil and Sediment Contamination: An International Journal, 28(8), 757-772.

McKeague, J., \& Day, J. (1966). Dithionite-and oxalate-extractable $\mathrm{Fe}$ and $\mathrm{Al}$ as aids in differentiating various classes of soils. Canadian Journal of Soil Science, 46(1), 13-22.

Meena, R., Datta, S. P., Golui, D., Dwivedi, B. S., \& Meena, M. C. (2016). Long-term impact of sewage irrigation on soil properties and assessing risk in relation to transfer of metals to human food chain. Environmental Science and Pollution Research, 23(14), 14269-14283.

Meharg, A. A. (2004). Arsenic in rice-understanding a new disaster for South-East Asia. Trends in Plant Science, 9(9), 415-417.

Mukhopadhyay, D. (2002). A study on arsenic mobilization, retention and interactions with organics in soils. Ph.D. thesis, Bidhan Chandra Krishi Viswavidyalaya, Mohanpur, West Bengal.

Olsen, S. R., Cole, C. V., Watanabe, F. S., \& and Dean, L. A. (1954). Estimation of available phosphorus in soil by extraction with sodium bicarbonate. Circular No. 939. Washington, DC: U.S. Department of Agriculture.

Rahaman, S., Sinha, A. C., Pati, R., \& Mukhopadhyay, D. (2013). Arsenic contamination: A potential hazard to the affected areas of West Bengal, India. Environmental Geochemistry and Health, 35(1), 119-132.

Roy, N., Das, A., Joardar, M., Ghosh, S., Bhowmick, S., \& Roychowdhury, T. (2018). Arsenic accumulation in paddy plants at different phases of pre-monsoon cultivation. Chemosphere, 210, 987-997. https://doi.org/10.1016/j. chemosphere.2018.07.041

Roy, N., Das, A., Mukherjee, M., Swain, S., Joardar, M., De, A., Mridha, D., \& Roychowdhury, T. (2020). Monsoonal paddy cultivation with phase-wise arsenic distribution in exposed and control sites of West Bengal, alongside its assimilation in rice grain. Journal of Hazardous Materials, 400, 123206. https://doi.org/10.1016/j.jhazmat.2020. 123206

Sanyal, S.K., Gupta, S.K., Kukal, S.S., \& Jeevan Rao, K. (2015). Soil degradation, pollution and amelioration. In: Pathak, H., Sanyal, S.K., Takkar, P.N. (Eds.), State of Indian Agriculture-Soil. National Academy of Agricultural Sciences, New Delhi, pp 234-266.

Singh, S. K. (2011). Arsenic contamination in water, soil, and food materials in Bihar. LAP LAMBERT Academic Publishing.

Singh, S. K., \& Ghosh, A. K. (2012). Health risk assessment due to groundwater arsenic contamination: Children are at high risk. Human and Ecological Risk Assessment: An International Journal, 18(4), 751-766.

Singh, S. K., Ghosh, A. K., Kumar, A., Kislay, K., Kumar, C., Tiwari, R. R., Parwez, R., Kumar, N., \& Imam, M. D. (2014). Groundwater arsenic contamination and associated health risks in Bihar, India. International Journal of Environmental Research, 8(1), 49-60.

Subbiah, B. V. \& Asija, G. L. (1956). A rapid procedure for estimation of available nitrogen in soil. Current Science, $25,259-260$.

Trang Hoang, T. Q., \& Hahn, C. (2015). Arsenic fractionation in agricultural soil in Vietnam using the sequential extraction procedure. In 4th International Conference on Informatics, Environment, Energy and Applications, Vol. 84 of IPCBEE, pp 123-127.

Van Nguyen, T., Osanai, Y., Do Nguyen, H., \& Kurosawa, K. (2017). Arsenic speciation and extraction and the significance of biodegradable acid on arsenic removal-An approach for remediation of arsenic-contaminated soil. International Journal of Environmental Research and Public Health, 14(9), 990.

Vogel, A. I., \& Svehla, G. (1996). Vogel's qualitative inorganic analysis. Longman.

Walkley, A., \& Black, I. A. (1934). An examination of the Degtjareff method for determining soil organic matter, and a proposed modification of the chromic acid titration method. Soil Science, 37(1), 29-38.

Wenzel, W. W., Kirchbaumer, N., Prohaska, T., Stingeder, G., Lombi, E., \& Adriano, D. C. (2001). Arsenic fractionation in soils using an improved sequential extraction procedure. Analytica Chimica Acta, 436(2), 309-323.

WHO. (1996). Trace elements in human nutrition and health. World Health Organization, Geneva.

Zheng, Q., Hou, J., Hartley, W., Ren, L., Wang, M., Tu, S., \& Tan, Wenfeng. (2020). As(III) adsorption on Fe-Mn binary oxides: Are Fe and Mn oxides synergistic or antagonistic for arsenic removal? Chemical Engineering Journal, 389, 124470.

Publisher's Note Springer Nature remains neutral with regard to jurisdictional claims in published maps and institutional affiliations. 